\title{
Evaluating approaches for sustaining methane production from coal through biogasification
}

\author{
Ji Zhang ${ }^{1}$, Yanna Liang ${ }^{1,2 *}$ \\ ${ }^{1}$ Department of Civil and Environmental Engineering, 1230 Lincoln Drive, Southern Illinois \\ University, Carbondale, IL 62901, USA. \\ ${ }^{2}$ Materials Technology Center, 1230 Lincoln Drive, Southern Illinois University, Carbondale, IL \\ 62901, USA. \\ * Corresponding author phone: 618-453-7808; fax: 618-453-3044 \\ E-mail: liangy@siu.edu
}

\begin{abstract}
Biogenic methane production from coal has been demonstrated to be a universal process at places where coal and a suitable microbial community co-exist. Through stimulating activities of in situ microbial communities, higher methane production rate can be achieved compared to those without biostimulation. However, it is commonly observed that upon stimulation either in situ or ex situ, methane production will increase but halt after certain period of time. This study was thus designed to identify reasons for this behavior and provide insight on how to sustain coal biogasification over longer durations. It was found out that after methane production rate stopped increasing, coal, at the studied loading, was still bioavailable. The headspace gas and the coal degradation intermediates were not toxic or inhibitory to the bioconversion process. Instead, lack of nutrients, especially those provided through yeast extract and peptone was critical for sustained methane release from coal. Although these two nutrients could be used as carbon
\end{abstract}


sources, negligible amount of methane was observed from control reactors without coal. At least, these were true for the microbial community and the bituminous coal investigated here. Thus, to convert coal to methane continuously at a high rate that is possible, site-specific nutrient solution needs to be supplemented periodically.

Keyword: bituminous coal, microbial community, sustained methane release, biogasification, nutrient solution

\section{Introduction}

During recent years, coal biogasification or bioconversion has attracted extensive interest globally among researchers and investors. Although coal is commonly recognized as recalcitrant and difficult to be degraded biologically, a wide variety of microbial communities that have the capability to gasify coal have been disclosed from different locations around the world, such as Yubai, Japan [1], Australia [2], the Waikato coalfields in New Zealand [3], the Alberta basin in Canada [4], the Eastern Ordos Basin in China [5], the Jingmen-Dangyang basin in China [6], the Illinois basin in the US [7, 8] and the Powder River Basin in the US [9, 10]. These communities generally include microorganisms in the two domains: Bacteria and Archaea.

Conventionally, coal biogasification is believed to require the collective actions of microorganisms encompassing three major metabolic groups: 1) hydrolytic and fermentative bacteria; 2) acetogenic bacteria, and 3) methanogenic archaea [11]. During the initial stage of gas production, complex organic compounds in coals are decomposed to simpler molecules such as acetate, long chain fatty acids, $\mathrm{CO}_{2}, \mathrm{H}_{2}, \mathrm{CH}_{4}$, and $\mathrm{HS}^{-}$by fermentative anaerobes. Fatty acids, 
alcohols, and some aromatic and amino acids are then converted to $\mathrm{H}_{2}, \mathrm{CO}_{2}$, and acetate by $\mathrm{H}_{2}$ producing acetogens while $\mathrm{H}_{2}$-using acetogenic bacteria consume $\mathrm{H}_{2}$ and $\mathrm{CO}_{2}$ to produce more acetate. Finally, simple molecules are subsequently transformed to $\mathrm{CH}_{4}$ by methanogens belonging to the domain of Archaea [12].

Depending on the methane formation pathways, methanogens are divided into three groups: 1) acetoclastic which converts acetate to methane and $\mathrm{CO}_{2} ; 2$ ) hydrogenotrophic which reduces $\mathrm{CO}_{2}$ to methane; and 3) methylotrophic which converts methylated compounds, such as methanol, methylamines and/or dimethylsulfide to methane [11]. Some methanogens, such as those within the order of Methanobacteriales [13] and Methanomicrobiales [14] can produce methane from more than one pathway. Very recently, it was reported that methanogens from the genus Methermicoccus can convert coal-derived methoxylated compounds directly to methane [15]. Without the presence of bacterial species, one isolate, M. shengliensis AmaM used more than 30 types of methoxylated aromatic compounds as substrates. When cultivated on lignite, subbituminous and bituminous coal, the methane produced was 10.8, 8.0 and $9.4 \mu \mathrm{mol} / \mathrm{g}$ coal, respectively [16]. The discovery of this novel pathway of methanogenesis makes research and development on coal biogasification even more interesting and exciting.

Coal biogasification can be conducted both in situ and ex situ. To study the mechanisms involved in coal bioconversion, a majority of research has been performed in a laboratory environment where in situ temperature and/or pressure may be simulated in a batch process. As reported by different researchers $[9,17-24]$, a common phenomenon has been observed: methane production (mass of methane per mass of coal) peaked and then either slowed down or stopped increasing after certain period of time. The possible explanations could be: 1) exhaustion of nutrients in the medium and coal used; 2) product inhibition: $\mathrm{CH}_{4}, \mathrm{H}_{2} \mathrm{~S}$ and $\mathrm{NH}_{3}$ in the headspace 
may inhibit microbial activities; 3) accumulation of toxic or inhibitory degradation products; and 4) the residual coal was not available to microbial cells [19].

To fully understand the reasons and to sustain coal biogasification for a longer duration, in this study, we established 18 microcosms that were exactly the same at the beginning of the experiment. Out of the 18, three reactors were used as controls. After 25 days, when methane production ceased, the other 15 microcosms were divided into five groups. Each group received different treatment in order for us to pinpoint the reasons for this production halt behavior. Based upon experimental results, strategies for sustaining methane release from coal were recommended.

\section{Materials and Method}

2.1. Coal, a microbial community and nutrient solution

Coal samples used in this study were the same as those described before $[17,18,25,26]$. Briefly, chunks of high volatile B bituminous coal from Illinois \# 6, the Herrin seam were ground first. Those passed mesh \#200 $(<74 \mu \mathrm{m})$ were sealed in ziplog bags and stored at room temperature. A microbial community that was enriched for ex situ coal bioconversion was employed for this investigation. As described in [25], the natural community in the formation water shifted significantly after it was cultivated in the laboratory environment for a month. The enriched community, however, is stable as long as the incubation conditions remain the same. This community comprised 185 Bacteria (98.3\% of the total sequences) and nine Archaea species (1.7\% of the total). The dominant Bacterial species were: Clostridium bifermentans (15.1\%), Massilia spp. (11.1\%), Pseudomonas putida (11.1\%), Proteiniphilum spp. (6.5\%), Pseudomonas stutzeri (6.4\%), Shewanella algae (5.7\%), Arcobacter spp. (5.3\%), Gelria spp. (2.8\%), 
Ruminococcus spp. (2.2\%), Methylobacterium aquaticum (2.0\%), Tindallia texcoconensis (2.0\%), and Syntrophomonas spp. (1.9\%). The main Archaea species were: Methanocalculus pumilus (43.9\%), Methanocalculus taiwanensis (42.7\%), Methanosarcina lacustris (7.1\%), Methanomicrobium spp. (3.5\%), Halobacterium spp. (1.0\%), Methanosaeta spp. (0.9\%), Thermoplasma spp. (0.5\%), Methanocalculus halotolerans (0.4\%), and Methanobacterium ferruginis $(0.01 \%)$. This community was stored with glycerol at $-80^{\circ} \mathrm{C}$. Fresh inoculum developed from these frozen stocks was used in this study (Fig. 1). It needs to be noted that the composition of the microbial community regenerated from the same frozen stocks but different times was found to be the same according to our next generation DNA sequencing results.

The nutrient solution was made according to the MS recipe [13] except that mercaptoethanesulfonic acid (Coenzyme M, CoM) was not included. This MS medium has been demonstrated to lead to more than 10-fold increase of methane release compared to those without the addition of this solution [25]. The MS recipe contained (per L of distilled and deionized water (DDW)): $8.4 \mathrm{~g}$ of $\mathrm{NaHCO}_{3}, 2.0 \mathrm{~g}$ of yeast extract, $2.0 \mathrm{~g}$ of trypticase peptones, $0.25 \mathrm{~g}$ of $\mathrm{Na}_{2} \mathrm{~S} \cdot 9 \mathrm{H}_{2} \mathrm{O}, 1.0 \mathrm{~g}$ of $\mathrm{NH}_{4} \mathrm{Cl}, 0.4 \mathrm{~g}$ of $\mathrm{K}_{2} \mathrm{HPO}_{4} \cdot 3 \mathrm{H}_{2} \mathrm{O}, 1.0 \mathrm{~g}$ of $\mathrm{MgCl}_{2} \cdot 6 \mathrm{H}_{2} \mathrm{O}, 0.4 \mathrm{~g}$ of $\mathrm{CaCl}_{2}, 1.0$ $\mathrm{mg}$ of resazurin, and $10 \mathrm{ml}$ of trace mineral solution. The trace mineral solution contained (per $\mathrm{L}$ of DDW): $500 \mathrm{mg}$ of NaEDTA. $2 \mathrm{H}_{2} \mathrm{O}, 150 \mathrm{mg}$ of $\mathrm{CoCl}_{2} \cdot 6 \mathrm{H}_{2} \mathrm{O}, 100 \mathrm{mg}$ of $\mathrm{MnCl}_{2} \cdot 4 \mathrm{H}_{2} \mathrm{O}, 100 \mathrm{mg}$ of $\mathrm{FeSO}_{4} \cdot 7 \mathrm{H}_{2} \mathrm{O}, 100 \mathrm{mg}$ of $\mathrm{ZnCl}_{2}, 40 \mathrm{mg}$ of $\mathrm{AlCl}_{3} \cdot 6 \mathrm{H}_{2} \mathrm{O}, 30 \mathrm{mg}$ of $\mathrm{Na}_{2} \mathrm{WO}_{4} \cdot 2 \mathrm{H}_{2} \mathrm{O}, 20 \mathrm{mg}$ of $\mathrm{CuCl}, 20 \mathrm{mg}$ of $\mathrm{Ni}_{2} \mathrm{SO}_{4} \cdot 6 \mathrm{H}_{2} \mathrm{O}, 10 \mathrm{mg}$ of $\mathrm{H}_{3} \mathrm{BO}_{3}, 10 \mathrm{mg}$ of $\mathrm{H}_{2} \mathrm{SeO}_{3}$, and $10 \mathrm{mg}$ of $\mathrm{Na}_{2} \mathrm{MoO}_{4} \cdot 2 \mathrm{H}_{2} \mathrm{O}$.

2.2. Setting up, monitoring and modifying microcosms 
A total of 18 microcosms (100 mL serum bottle) was established. Out of the 18 , three microcosms served as controls where coal was not added. These three contained only $45 \mathrm{~mL}$ of the MS medium, $100 \mathrm{mM}$ of ethanol and $5 \mathrm{~mL}$ inoculum developed from the microbial community aforementioned. Each of the remaining 15 microcosms contained coal at $201.98 \mathrm{~g} / \mathrm{L}$ and received $45 \mathrm{~mL}$ of the $\mathrm{MS}$ solution, $100 \mathrm{mM}$ of ethanol and $5 \mathrm{~mL}$ inoculum. After all ingredients were added, the bottles were capped with butyl rubber stoppers and sealed with aluminum crimps. All bottles were purged with $\mathrm{N}_{2}$ completely and then incubated at $32^{\circ} \mathrm{C}$ under static conditions. Starting from day 10, the headspace gas in each bottle was released and measured according to a protocol reported before [17]. Briefly, when a needle was inserted into the headspace, the pressurized gas due to gas production from coal would escape to a 50-mL gas tight syringe connected to the needle. The volume of the released gas together with gas content measured by a Gas Chromatography (GC) as detailed below were recorded for calculating cumulative methane production at different time points.

On day 25, the total nitrogen (TN) and total phosphorous (TP) content of the liquid in each bottle were analyzed according to procedures detailed below. The 15 bottles that contained coal were then divided into five groups with each group having three replicates (Fig. 1 and Table 1). The first set was kept the same with no changes. To the second group, a concentrated solution of $\mathrm{K}_{2} \mathrm{HPO}_{4} \cdot 3 \mathrm{H}_{2} \mathrm{O}$ was added to make the TP concentration equal to the original level. To the third group, a concentrated MS solution without yeast extract, peptone, $\mathrm{NH}_{4} \mathrm{Cl}$, and $\mathrm{K}_{2} \mathrm{HPO}_{4} \cdot 3 \mathrm{H}_{2} \mathrm{O}$ was supplemented to each bottle. This supplementation was equal to adding fresh MS medium without compounds containing $\mathrm{N}$ and $\mathrm{P}$ at $20 \%$ of the initial liquid volume. Regarding the fourth group of three, the headspace was purged with pure nitrogen to displace the 
whole headspace content. In terms of the fifth group, $20 \%$ of the liquid in each bottle was withdrawn followed by adding fresh MS solution at the same volume.

After these treatments, all of the 15 bottles were monitored for 10 days. On day 35, the first set of the three controls were sparged with $\mathrm{N}_{2}$ to replace their headspace followed by adding $5 \mathrm{~mL}$ of fresh cells and $45 \mathrm{~mL}$ of MS medium to each. To the second set, concentrated yeast extract and peptone were added at $2 \mathrm{~g} / \mathrm{L}$ for each. To the third group, fresh community $(5 \mathrm{~mL})$ was supplemented. For the fourth group, half liquid volume was replaced by fresh MS medium at the same volume together with $2.5 \mathrm{~mL}$ fresh culture. For the fifth group, half liquid volume was withdrawn and the same volume of fresh MS solution but without fresh cells was filled back. After all modifications were performed, the microcosms were monitored for another 20 days. All treatments were summarized in Table 1.

\subsection{Analysis}

Content of methane, nitrogen and $\mathrm{CO}_{2}$ in the microcosm headspace was analyzed through a $17 \mathrm{~A}$ GC (Shimadzu, Columbia, MD, USA). This GC was equipped with a $60 \mathrm{~m} \times 0.53 \mathrm{~mm}$ RTMsieve 5A porous layer molecular sieve (Restek, Bellefonte, PA, USA) and a flame ionization detector with argon being the carrier gas with a flow rate of $10.1 \mathrm{~mL} / \mathrm{min}$. The isothermal zone temperatures for the injector and detector were set at $75^{\circ} \mathrm{C}$ and $310^{\circ} \mathrm{C}$, respectively. The retention time for methane was 4.73 min. Calibration curves for methane (5-99\%) was established using standard gases (Air Liquide, Plumsteadville, PA, USA). TN and TP were analyzed through use of Hach kit TNT 827and Hach kit TNT 844, respectively.

\section{Results and discussion}


As described above, this study was designed to gain insights on why methane ceases to be produced from coal after certain period of time. This phenomenon was observed again in this work as shown in Fig. 2-6. On day 20, the average methane production for the 15 microcosms containing coal was $929.0 \pm 99.9 \mathrm{ft}^{3} /$ ton. On day 25 , the average was $969.5 \pm 98.0 \mathrm{ft}^{3} /$ ton. Thus, methane release basically stopped after day 20 .

The treatments made to different groups of microcosms were aimed to answer five questions. First, was coal still bioavailable after methane production started to level off? Second, were decreased concentrations of $\mathrm{N}$ and $\mathrm{P}$ responsible for methane release halt? Third, were decreased concentrations of compounds other than those containing $\mathrm{N}$ and $\mathrm{P}$ contribute to decreased methane content? Fourth, were the intermediates from coal degradation inhibitory to the microbial community? Fifth, was the headspace gas toxic to the microorganisms?

To answer the first question, the three microcosms in Group \#1 received no modifications before day 35. As shown in Fig. 2, methane content reached the highest at $72 \%$ and methane yield peaked at $833.7 \mathrm{ft}^{3} /$ ton on day 20 . After this date, methane content in these reactors kept dropping to $53 \%$ while cumulative methane production had no changes. Between day 20 and 35, the community still continuously produced biogas although the volume was much lower compared to those observed in the first 20 days. At day 35, the entire aqueous phase in these reactors was replaced with fresh MS medium and fresh cells and the headspace was purged with $\mathrm{N}_{2}$ completely. As a result, the headspace methane content increased immediately from $0.0 \%$ to $61.7 \%$ on day 45 and $70 \%$ on day 55 . Since complete withdrawal of the original liquid phase also removed potentially soluble compounds dissolved from coal, the newly generated methane after day 35 must be from coal itself and/or compounds attached or bond to the coal. Therefore, the coal in each reactor was still available to the microbial community and amenable 
to further degradation. This confirmed the assumption proposed by Green et al [19] that the remaining coal should be bioavailable given the low conversion of $0.13 \%$ observed in that study. Loading of coal has been recognized as one of the most important factors affecting enhanced biogenic coal-bed methane generation. When coal content was above $4 \%(\mathrm{w} / \mathrm{v})$, decreased coal conversion to methane was observed [24]. And some studies have shown that coal is the yield-limiting nutrient [22]. In this study, the coal loading used was $20.2 \%$ (w/v) which was much higher than others reported. This loading was obtained through an optimization study [17] and toxicity from coal at this high content has not been observed for the microbial community used here. Results from the Group 1 reactors also revealed that coal was not the ratelimiting substrate.

It needs to be noted that $100 \mathrm{mM}$ ethanol was added to all of the 18 microcosms on day 0 . Use of ethanol at this concentration for coal biogasification has been proven to be the optimal condition for maximizing methane yield [17]. To address the question of how much methane could be produced from ethanol and yeast extract and peptone included in the adopted nutrient solution by the target microbial community, three controls without coal were set up as detailed above. Surprisingly, only $6.0 \pm 1.7 \mathrm{~mL}$ of methane was detected in these three reactors on day 10. After this date, no more methane was produced. Hence, on average, for the 15 microcosms that contained coal, $97.6 \%$ of methane observed in the first 25 days was from coal. Similar observations were also reported by other studies that methane release from the nutrient solution was minimal when coal was not provided [18]. Thus, the coal may be providing a favorable environment to the microorganisms that results in enhanced methane production compared to those without coal [4]. 
As aforementioned, the community used in this study comprised archaea mainly in the order of Methanomicrobiales. These methanogens can use formate and alcohol as substrates besides $\mathrm{H}_{2}$ [14]. Our previous research has shown that 2-propanol and sodium formate had no significant effect on methane production from coal by this microbial consortium. Ethanol, however, had the most positive impact on this regard [17]. In the process of coal bioconversion, ethanol may serve two roles. First, it could be a carbon source and electron donor that can be converted to methane indirectly. Through ${ }^{13} \mathrm{C}$ tracer tests, ethanol was found to account for 6,14 , and $2.5 \%$ of the total carbon flux to methane in anoxic environments of Lake Mendota, Knaack Lake and sewage digester sludge, respectively [27]. Second, ethanol could be a solvent that can increase coal solubility. In one study, enhanced methane production was observed only when ethanol was added in the amount of 5 or $10 \mathrm{mg}$ to $10 \mathrm{~g}$ coal from Power River Basin [28].

Anaerobic ethanol biodegradation is reported to take place in two sequential steps [29]. In the first stage, acetate and $\mathrm{H}_{2}$ are produced from ethanol (Equation 1). In the second stage, acetate is converted to methane and $\mathrm{CO}_{2}$ by acetoclastic methanogenesis (Equation 2) and $\mathrm{CO}_{2}$ is transformed to methane through hydrogenotrophic pathway (Equation 3). Thus, the overall reaction from ethanol to methane is shown in Equation 4. According to this overall reaction, if all ethanol is converted to methane, then $100 \mathrm{mM}$ ethanol in the microcosms would lead to $184 \mathrm{~mL}$ methane at $1 \mathrm{~atm}$ and $25^{\circ} \mathrm{C}$. However, in the three control reactors where no coal was present, the released methane was only around $6.0 \mathrm{~mL}$. Thus, the role of ethanol in coal biogasification might be inclined to the second function as a solvent. At least, for the microbial community studied here, this could be true. Further work is needed, though to prove this hypothesis.

Ethanol to acetate: $\mathrm{CH}_{3} \mathrm{CH}_{2} \mathrm{OH}+\mathrm{H}_{2} \mathrm{O} \rightarrow 2 \mathrm{H}_{2}+\mathrm{CH}_{3} \mathrm{COO}^{-}+\mathrm{H}^{+}$ 
Acetate to methane: $\mathrm{CH}_{3} \mathrm{COO}^{-}+\mathrm{H}^{+} \rightarrow \mathrm{CH}_{4}+\mathrm{CO}_{2}$

Carbon dioxide to methane: $\mathrm{CO}_{2}+4 \mathrm{H}_{2} \rightarrow \mathrm{CH}_{4}+2 \mathrm{H}_{2} \mathrm{O}$

The overall conversion of ethanol to methane: $2 \mathrm{CH}_{3} \mathrm{CH}_{2} \mathrm{OH} \rightarrow 3 \mathrm{CH}_{4}+\mathrm{CO}_{2}$

To answer the second question of whether the decreased concentrations of nitrogen and phosphorous limited methane release, the TN and TP contents of the liquid in each bottle on day 0 were measured as 614.0 and $22.8 \mathrm{mg} / \mathrm{L}$, respectively. On day 25 , the TN concentration was $428.0 \pm 14 \mathrm{mg} / \mathrm{L}$ and the TP was $4.1 \pm 2.7 \mathrm{mg} / \mathrm{L}$. In these 25 days, $30.3 \%$ and $82.1 \%$ of TN and TP were utilized, respectively. In the original MS medium, the main source of TP came from $\mathrm{K}_{2} \mathrm{HPO}_{4} \cdot 3 \mathrm{H}_{2} \mathrm{O}$ at $0.4 \mathrm{~g} / \mathrm{L}$. Thus, to determine whether the decreased content of TP was a ratelimiting factor, a $100 \mu \mathrm{l}$ concentrated stock solution of this chemical was added to each of the Group \#2 microcosms to bring up the TP concentration to its initial level. However, as shown in Fig. 3, the methane content kept dropping from the highest $73.7 \%$ on day 15 to $49 \%$ on day 30 . It was only after yeast extract and peptone were added on day 35 , the methane content started to rise. The initial increase from $49.3 \%$ on day 35 to $68 \%$ on day 40 was rapid. However, although the methane yield increased steadily, the methane content did not increase much after day 40 and dropped again after day 50. Therefore, supplying TN and TP through yeast extract and peptone worked to certain extent while adding $\mathrm{K}_{2} \mathrm{HPO}_{4} \cdot 3 \mathrm{H}_{2} \mathrm{O}$ did not have any positive effect on methane production.

Since adding TP in the form of $\mathrm{K}_{2} \mathrm{HPO}_{4} \cdot 3 \mathrm{H}_{2} \mathrm{O}$ led to no methane release increase, we then tested whether the other inorganic ingredients in the MS recipe were the limiting factors. This was to address question \#3 (Fig. 1). In this case, a concentrated stock solution (0.9 mL) of the MS medium but without yeast extract, peptone, $\mathrm{NH}_{4} \mathrm{Cl}$, and $\mathrm{K}_{2} \mathrm{HPO}_{4}$, was added to each of 
the Group \#3 microcosms in a strength that was $20 \%$ of the initial concentration for each compound. As indicated by Fig. 4, this addition did not result in any positive changes of methane yield with methane content keeping dropping. Methane content increased again when 10\% (5 $\mathrm{mL}$ ) of fresh inoculum was supplemented. However, the increase of methane content from $49.3 \%$ on day 35 to $73.0 \%$ on day 45 only lasted for 10 days. After day 45 , headspace methane content started decreasing while methane yield increased continuously. Therefore, adding fresh cultures did seem to be beneficial for sustaining methane production. But, since the added cells carried the MS medium, it was difficult to ascertain what exactly stimulated methane release, the cells or the MS medium. To eliminate the nutrient solution from being carried by the cells, we could wash the community. However, considering the facts: 1) the inoculum might be contaminated during the wash process and 2) it is difficult to evaluate whether a microbial consortium is contaminated, this washing step was not adopted.

To understand whether the newly added cells or the MS medium led to methane production increase, $10 \mathrm{~mL}$ liquid (20\% of the total aqueous volume) was withdrawn and replaced with the fresh MS medium at the same volume for the Group \#4 microcosms. No significant changes occurred as a result of this action (Fig. 5). Thus, the increased methane yield observed from Group \#3 reactors should be mainly due to the newly supplemented cells. In addition, this action of withdrawing used and replenishing fresh medium was to see whether coal degradation intermediates were toxic to the cells. If they were, then dilution with fresh medium should alleviate this negative effect. As shown in Fig. 5, further dilution by replacing 50\% of the liquid by the fresh MS medium plus headspace gas purging did lead to increased methane production. On day 40 , the methane content reached $69.5 \%$ from $0 \%$ on day 35 due to $\mathrm{N}_{2}$ gas purging. After day 40, however, the methane content was relatively stable while methane yield 
kept increasing. This increase could be due to: 1) releasing potentially toxic gases $\left(\mathrm{H}_{2} \mathrm{~S}, \mathrm{NH}_{3}\right)$ from the headspace, 2) dilution of the compounds formed from coal depolymerization by the target microbial community and 3) the fresh MS medium stimulated methane production. For the latter, since inorganic components in the nutrient solution did not exert positive effects to Group \#3 reactors, the stimulating effect must be from yeast extract and peptone. This agrees well with what we have observed previously that these two components are crucial for the microbial community studied here. When the concentrations of these two were lower than $2 \mathrm{~g} / \mathrm{L}$, methane yield decreased significantly and proportionally to concentration of these two nutrient sources. In addition, yeast extract was demonstrated to have a greater stimulating role than peptone [18]. This explained why replacing $20 \%$ of the total liquid volume did not lead to much methane release, but methane production increased dramatically when a 50\% replacement was used for Group \#3 microcosms.

Yeast extract contains vitamins, amino acids and trace minerals. It has been used broadly as a non-specific stimulant in different nutrient solutions designed to stimulate coal biogasification [30]. Additionally, this ingredient is known to act as a chelating species that may be able to increase coal solubility and biodegradation [31]. However, this nutrient source was also found to exert inhibitory effect on methanogenesis relative to those without this supplement when low rank coal from Fort Yukon, Alaska was biogasified by naturally-occurring microorganisms associated with the coal [20]. Hence, use of this substance is highly dependent on the coal and microbial communities specific to different basins.

To elucidate whether headspace gas purging was critical for renewed methane production, the headspace in each of the Group \#5 microcosms were purged completely with $\mathrm{N}_{2}$ gas on day 25. As a result, methane content reached $10.4 \%$ after 5 days but increased no more 
thereafter (Fig. 6). Thus, for Group \#4 microcosms, the observed methane increase should be mainly due to the medium replacement. In light of this observation, for Group \#5 reactors, half of the liquid was replaced with fresh MS medium at the same volume together with half of the inoculum initially added. As a consequence, methane content increased steadily from $10.6 \%$ on day 35 to $52 \%$ on day 55 while methane yield increased slowly from $924.3 \mathrm{ft}^{3} /$ ton on day 35 to $1145.3 \mathrm{ft}^{3} /$ ton on day 55 .

Before this experiment, we conducted a study on effect of ethanol on methane production [17]. Briefly, methane production rate $\left(\mathrm{ft}^{3} /\right.$ ton-day) of $65.5,64.6$ and 63.2 was observed during the first 15 days, from day 25 to day 40 and between day 40 and day 55, respectively. Basically the same amount of methane release was attained after each dose of ethanol $(100 \mathrm{mM})$ was added to the same microcosms. This could lead to the conclusion that the majority of methane was from ethanol. However, as shown in this study, with only ethanol and the nutrient solution, the same microbial community produced ignorable amount of methane. The fact that the same methane production rate was observed again and again also testify that coal degradation products did not have inhibitory effects on the microbial consortium.

Therefore, together with the results reported here, it was clear that: 1) coal was still bioavailable after methane yield stopped increasing; 2) supplementing inorganic phosphorouscontaining compounds, such as $\mathrm{K}_{2} \mathrm{HPO}_{4}$, did not lead to increased methane release; 3) replenishing compounds other than those containing $\mathrm{N}$ and $\mathrm{P}$ in the $\mathrm{MS}$ recipe did not exert significant positive effects on methane production. In terms of maintaining the potency of the nutrient solution, yeast extract and peptone, the commonly used sources for $\mathrm{N}$ were crucial for continued biogasification; 4) coal degradation intermediates did not pose negative effects on further coal degradation; and 5) the headspace gas was not toxic. 
Based on these insights, sustained methane production from coal can be accomplished by: 1) replacing the whole liquid volume and adding fresh inoculum after methane release stops. This approach led to a methane production rate of $24.15 \mathrm{ft}^{3} /$ ton-day after this treatment (Table 1); 2) adding key ingredients, such as yeast extract and peptone when the microbial community ceases to produce methane. This addition resulted in a methane release rate of $18.04 \mathrm{ft}^{3} /$ ton-day. Other methods, such as only supplementing cells or replacing part of the used nutrient solution, were beneficial for renewing methane release. The potency, however was less than the first two treatments.

The highest methane production rate of $24.15 \mathrm{ft}^{3} /$ ton-day observed between day 35 and 55 , is still lower than $38.78 \pm 3.92 \mathrm{ft}^{3} /$ ton-day during the initial 25 days. This could be due to the possibility that easily accessible and degradable compounds associated with coal are converted to methane at the beginning stage of biogasification. Once these chemicals are consumed, the microbes have to utilize more recalcitrant fractions of coal to survive, which results in slower methane release rate even after nutrients are replenished. Exactly, what fractions of coal are amenable to microbial degradation is still a debated issue. Both positive [21] and negative [32, 33] correlation between coal ranking or maturity and maximum methanogenic rates have been reported. In addition, other questions, such as how much coal can be degraded if nutrients are amended periodically remain to be addressed.

The strategies revealed here for sustaining methane production from coal can be certainly and easily applied ex situ. The exact duration for how long coal can be continuously gasified to methane will need to be further investigated. In the case of in situ, withdrawing all formation water and replacing it with specific nutrient solution is not practical. But supplementing key 
nutrient ingredients periodically can definitely enhance methane production continuously. The frequency for providing these nutrients, however, will be site dependent.

\section{Conclusion}

Through investigating different possible factors that could affect continued methane production from coal, several questions raised by different investigators were answered in this study. It was discovered that coal could be converted to methane continuously if optimal conditions were maintained. When methane production halts and methane content starts decreasing, replacing the used medium and cells periodically could sustain methane release from coal. Additionally, among different ingredients in the nutrient recipe, yeast extract and peptone were proven to be the most important. And for the studied microbial community, adding only yeast extract and peptone was also able to renew coal biogasification. The frequency of these replenishments will be dependent on the trend of methane production and be specific to the target coal and microbes.

\section{Acknowledgement}

We gratefully acknowledge support from the Department of Energy of the United States under Award Number DE-FE0024126 and DE-FE0026161.

\section{Disclaimer}

This report was prepared as an account of work sponsored by an agency of the United States Government. Neither the United States Government nor any agency thereof, nor any of their employees, makes any warranty, express or implied, or assumes any legal liability or 
responsibility for the accuracy, completeness, or usefulness of any information, apparatus, product, or process disclosed, or represents that its use would not infringe privately owned rights. Reference herein to any specific commercial product, process, or service by trade name, trademark, manufacturer, or otherwise does not necessarily constitute or imply its endorsement, recommendation, or favoring by the United States Government or any agency thereof. The views and opinions of authors expressed herein do not necessarily state or reflect those of the United States Government or any agency thereof."

\section{Table titles}

Table 1: Summary of treatments and effects for different microcosms at different time points.

\section{Figure legends}

Fig. 1: The overall design of this experiment.

Fig. 2: Methane yield and content responding to replacement of the entire aqueous phase.

Fig. 3: Methane yield and content responding to addition of nitrogen and phosphorous. YE: yeast extract; P: peptone.

Fig. 4: Methane yield and content responding to addition of inorganic compounds and fresh cells. Fig. 5: Methane yield and content responding to medium replacement at different strength.

Fig. 6: Methane yield and content responding to headspace purge and replacement of 50\% of the aqueous phase in each reactor. 


\section{References}

[1] S. Shimizu, M. Akiyama, T. Naganuma, M. Fujioka, M. Nako, Y. Ishijima, Molecular characterization of microbial communities in deep coal seam groundwater of northern Japan, Geobiology, 5 (2007) 423-433.

[2] D. Li, P. Hendry, M. Faiz, A survey of the microbial populations in some Australian coalbed methane reservoirs, International Journal of Coal Geology, 76 (2008) 14-24.

[3] J.C. Fry, B. Horsfield, R. Sykes, B.A. Cragg, C. Heywood, G.T. Kim, K. Mangelsdorf, D.C. Mildenhall, J. Rinna, A. Vieth, Prokaryotic populations and activities in an interbedded coal deposit, including a previously deeply buried section $(1.6-2.3 \mathrm{~km})$ above 150 Ma basement rock, Geomicrobiology Journal, 26 (2009) 163-178.

[4] T.J. Penner, J.M. Foght, K. Budwill, Microbial diversity of western Canadian subsurface coal beds and methanogenic coal enrichment cultures, International Journal of Coal Geology, 82 (2010) 81-93.

[5] H. Guo, R. Liu, Z. Yu, H. Zhang, J. Yun, Y. Li, X. Liu, J. Pan, Pyrosequencing reveals the dominance of methylotrophic methanogenesis in a coal bed methane reservoir associated with Eastern Ordos Basin in China, International Journal of Coal Geology, 93 (2012) 56-61.

[6] M. Wei, Z. Yu, Z. Jiang, H. Zhang, Microbial diversity and biogenic methane potential of a thermogenic-gas coal mine, International Journal of Coal Geology, 134-135 (2014) 96-107.

[7] J. Zhang, Y. Liang, R. Pandey, S. Harpalani, Characterizing microbial communities dedicated for conversion of coal to methane in situ and ex situ, International Journal of Coal Geology, 146 (2015) 145-154. 
[8] D. Strąpoć, F.W. Picardal, C. Turich, I. Schaperdoth, J.L. Macalady, J.S. Lipp, Y.-S. Lin, T.F. Ertefai, F. Schubotz, K.-U. Hinrichs, Methane-producing microbial community in a coal bed of the Illinois Basin, Applied and Environmental Microbiology, 74 (2008) 2424-2432.

[9] L.K. Gallagher, A.W. Glossner, L.L. Landkamer, L.A. Figueroa, K.W. Mandernack, J. Munakata-Marr, The effect of coal oxidation on methane production and microbial community structure in Powder River Basin coal, International Journal of Coal Geology, 115 (2013) 71-78. [10] D.A. Klein, R.M. Flores, C. Venot, K. Gabbert, R. Schmidt, G.D. Stricker, A. Pruden, K. Mandernack, Molecular sequences derived from Paleocene Fort Union Formation coals vs. associated produced waters: Implications for CBM regeneration, International Journal of Coal Geology, 76 (2008) 3-13.

[11] S.Y. Park, Y. Liang, Biogenic methane production from coal: A review on recent research and development on microbially enhanced coalbed methane (MECBM), Fuel, 166 (2016) 258267.

[12] M. Faiz, P. Hendry, Significance of microbial activity in Australian coal bed methane reservoirs - A review, Bulletin of Canadian Petroleum Geology, 54 (2006) 261-272.

[13] A.S. Bonin, D.R. Boone, The order methanobacteriales, in: The Prokaryotes, Springer, 2006, pp. 231-243.

[14] J.-L. Garcia, B. Ollivier, W.B. Whitman, The order Methanomicrobiales, in: The prokaryotes, Springer, 2006, pp. 208-230.

[15] C.U. Welte, A microbial route from coal to gas, Science, 354 (2016) 184-184.

[16] D. Mayumi, H. Mochimaru, H. Tamaki, K. Yamamoto, H. Yoshioka, Y. Suzuki, Y. Kamagata, S. Sakata, Methane production from coal by a single methanogen, Science, 354 (2016) 222-225. 
[17] J. Zhang, Y. Liang, S. Harpalani, Optimization of methane production from bituminous coal through biogasification, Applied Energy, 183 (2016) 31-42.

[18] J. Zhang, S.Y. Park, Y. Liang, S. Harpalani, Finding cost-effective nutrient solutions and evaluating environmental conditions for biogasifying bituminous coal to methane ex situ, Applied Energy, 165 (2016) 559-568.

[19] M.S. Green, K.C. Flanegan, P.C. Gilcrease, Characterization of a methanogenic consortium enriched from a coalbed methane well in the Powder River Basin, USA, International Journal of Coal Geology, 76 (2008) 34-45.

[20] S.H. Harris, R.L. Smith, C.E. Barker, Microbial and chemical factors influencing methane production in laboratory incubations of low-rank subsurface coals, International Journal of Coal Geology, 76 (2008) 46-51.

[21] P.H. Fallgren, S. Jin, C. Zeng, Z. Ren, A. Lu, P.J.S. Colberg, Comparison of coal rank for enhanced biogenic natural gas production, International Journal of Coal Geology, 115 (2013) 9296.

[22] S.L. Papendick, K.R. Downs, K.D. Vo, S.K. Hamilton, G.K. Dawson, S.D. Golding, P.C. Gilcrease, Biogenic methane potential for Surat Basin, Queensland coal seams, International Journal of Coal Geology, 88 (2011) 123-134.

[23] P. Gupta, A. Gupta, Biogas production from coal via anaerobic fermentation, Fuel, 118 (2014) 238-242.

[24] R. Rathi, A. Priya, M. Vohra, M. Lavania, B. Lal, P.M. Sarma, Development of a microbial process for methane generation from bituminous coal at thermophilic conditions, International Journal of Coal Geology, 147-148 (2015) 25-34. 
[25] J. Zhang, Y. Liang, R. Pandey, S. Harpalani, Characterizing microbial communities dedicated for conversion of coal to methane in situ and ex situ, International Journal of Coal Geology, 146 (2015) 145-154.

[26] J. Zhang, Y. Liang, P.M. Yau, R. Pandey, S. Harpalani, A metaproteomic approach for identifying proteins in anaerobic bioreactors converting coal to methane, International Journal of Coal Geology, 146 (2015) 91-103.

[27] B. Schink, T.J. Phelps, B. Eichler, J. Zeikus, Comparison of ethanol degradation pathways in anoxic freshwater environments, Journal of General Microbiology, 131 (1985) 651-660. [28] Y. Liu, M.A. Urynowicz, D.M. Bagley, Ethanol conversion to methane by a coal microbial community, International Journal of Coal Geology, 115 (2013) 85-91.

[29] J.G. Freitas, B. Fletcher, R. Aravena, J.F. Barker, Methane production and isotopic fingerprinting in ethanol fuel contaminated sites, Ground Water, 48 (2010) 844-857.

[30] D. Ritter, D. Vinson, E. Barnhart, D.M. Akob, M.W. Fields, A.B. Cunningham, W. Orem, J.C. McIntosh, Enhanced microbial coalbed methane generation: A review of research, commercial activity, and remaining challenges, International Journal of Coal Geology, 146 (2015) 28-41.

[31] R. Fakoussa, M. Hofrichter, Biotechnology and microbiology of coal degradation, Applied Microbiology and Biotechnology, 52 (1999) 25-40.

[32] D. Strąpoć, M. Mastalerz, K. Dawson, J. Macalady, A.V. Callaghan, B. Wawrik, C. Turich, M. Ashby, Biogeochemistry of microbial coal-bed methane, Annual Review of Earth and Planetary Sciences, 39 (2011). 617-656. 
[33] E.J.P. Jones, M.A. Voytek, P.D. Warwick, M.D. Corum, A. Cohn, J.E. Bunnell, A.C. Clark, W.H. Orem, Bioassay for estimating the biogenic methane-generating potential of coal samples, International Journal of Coal Geology, 76 (2008) 138-150. 
Fig. 1: The overall design of this experiment

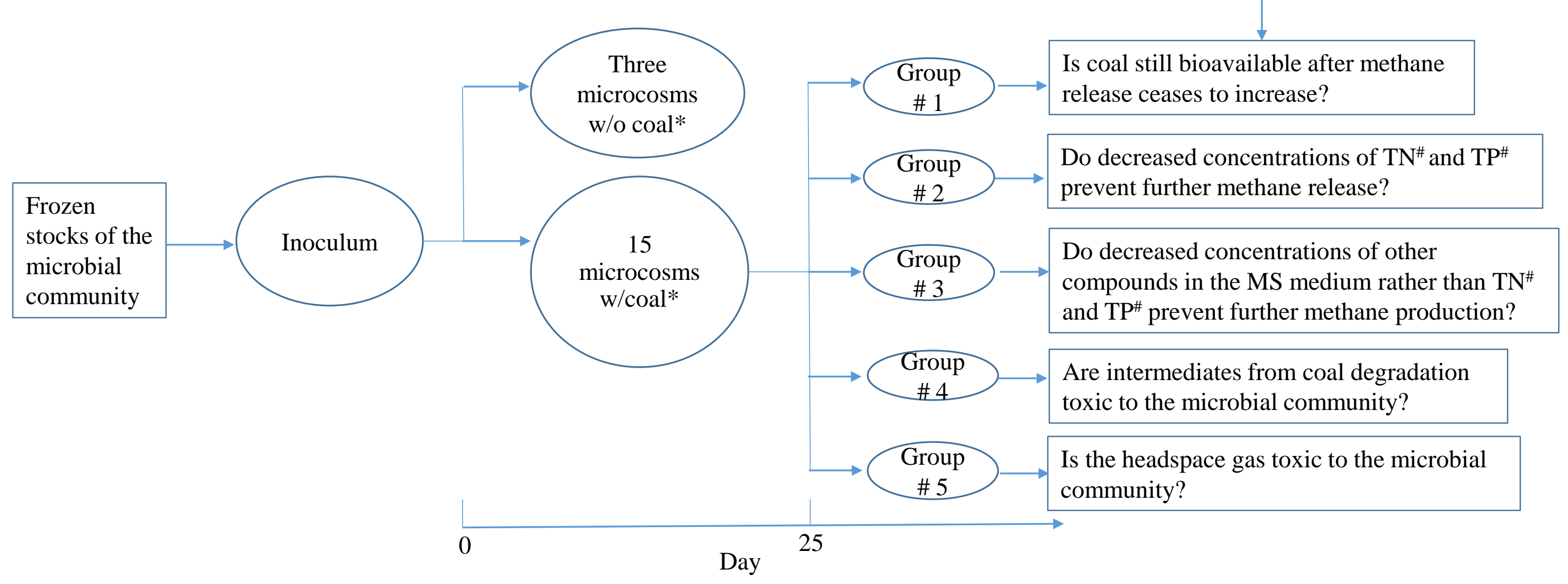

*: The same MS medium with ethanol at $100 \mathrm{mM}$ was used.

\#: TN: total nitrogen; TP: total phosphorous. 


\section{Table 1: Summary of treatments at different time points.}

\section{Group Treatment on day 25}

\#1 None

\#2 Add $100 \mu$ l stock solution of $\mathrm{K}_{2} \mathrm{HPO}_{4}{ }^{* 1}$

Add $0.9 \mathrm{~mL}$ concentrated MS medium exfect

\#4

Replace $20 \%$ of used medium with fresh solution at the same volume

\#5 Purge the headspace gas completely

*: Concentrated stock solutions were used in order not to change the total liquid volume in each microcosm.

1: This volume was added to make the TP equal to its original concentration.

2. This volume was used to provide $20 \%$ of inorganic compounds initially in the MS medium.

NA: Not applicable.
Methane production rate day $35-55\left(\mathbf{f t}^{3} /\right.$ ton/day $)$

Purge with $\mathrm{N}_{2}$ to remove headspace gas completely. Add $5 \mathrm{~mL}$

cells and $45 \mathrm{~mL}$ of MS medium to each.

Add yeast extract and peptone each at $2 \mathrm{~g} / \mathrm{L}$

24.15

Add $5 \mathrm{~mL}$ of fresh cells to each

Purge the headspace gas, replace $50 \%$ of used medium with fresh solution at the same volume

18.04

Positive but marginal

effect

Positive but marginal Replace $50 \%$ of used medium with fresh solution at the same volume $+50 \%$ of initial cells

11.07

\begin{tabular}{l}
$\left(\mathbf{f t}^{3} /\right.$ ton/day $)$ \\
\hline .15 \\
8.04 \\
4.90 \\
5.08 \\
1.07
\end{tabular}


Fig. 2: Methane yield and content responding to replacement of the entire aqueous phase.

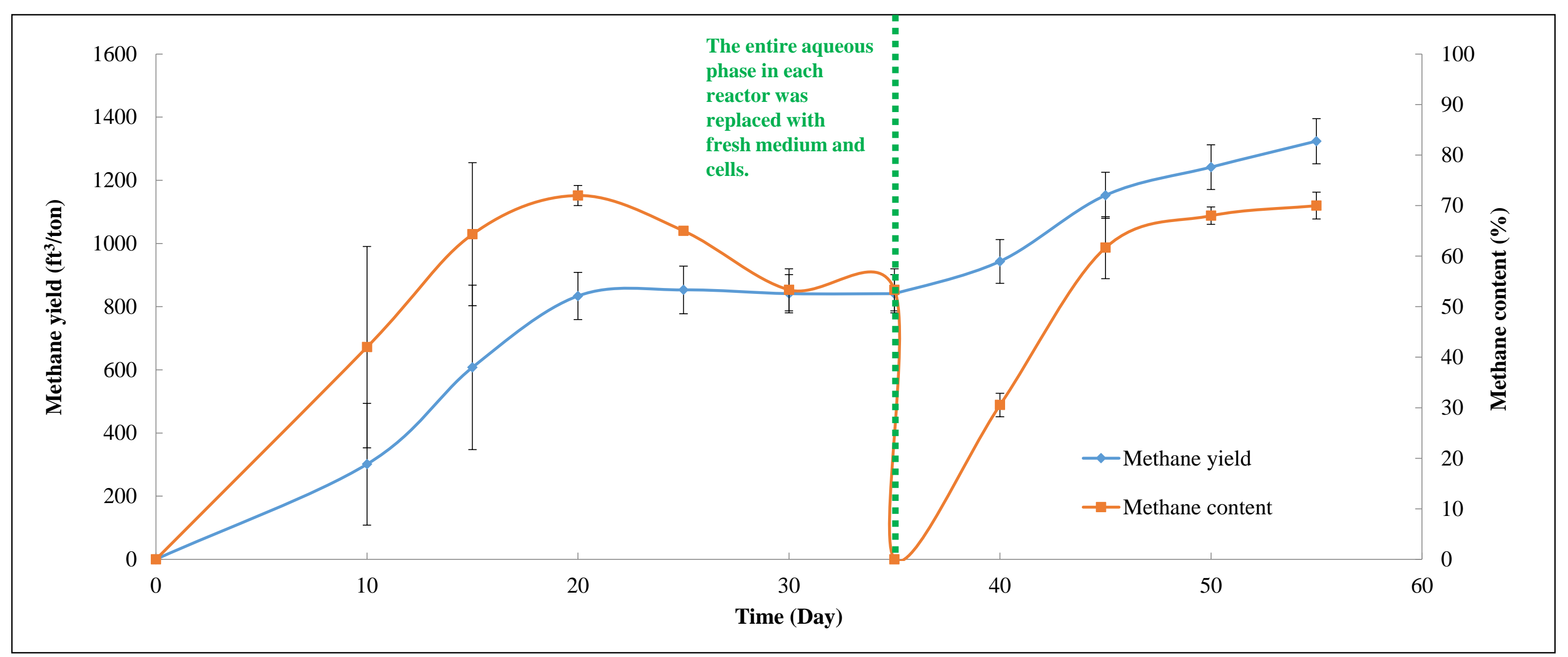


Fig. 3: Methane yield and content responding to addition of nitrogen and phosphorous.

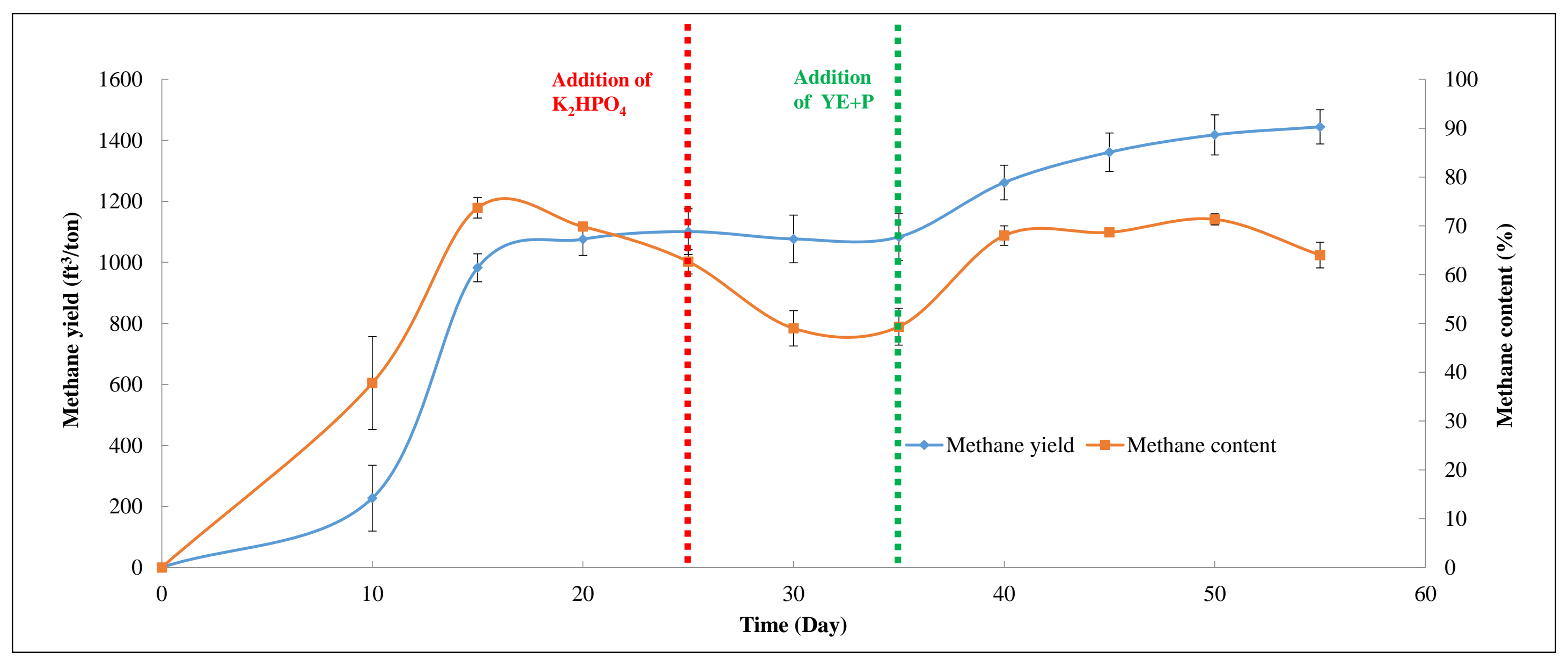


Fig. 4: Methane yield and content responding to addition of inorganic compounds and fresh cells.

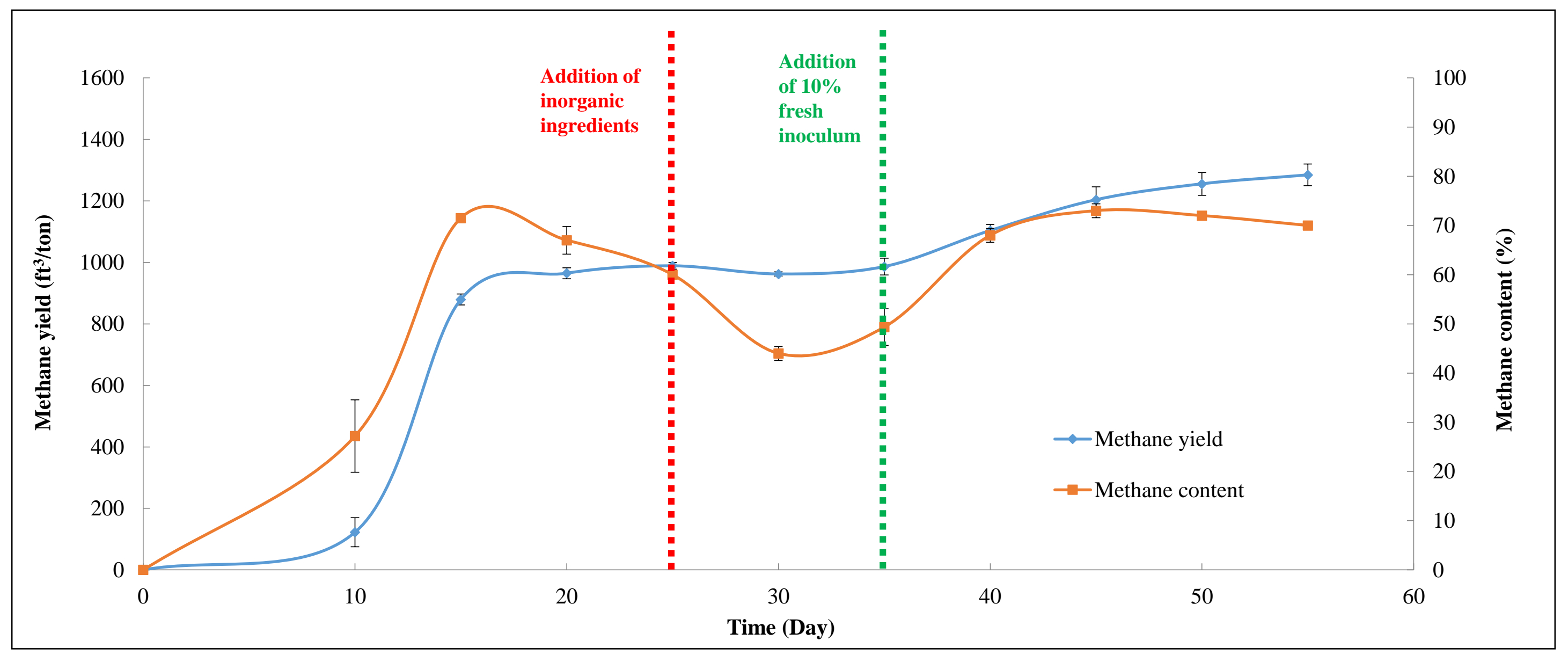




\section{Fig. 5: Methane yield and content responding to medium replacement at different strength.}

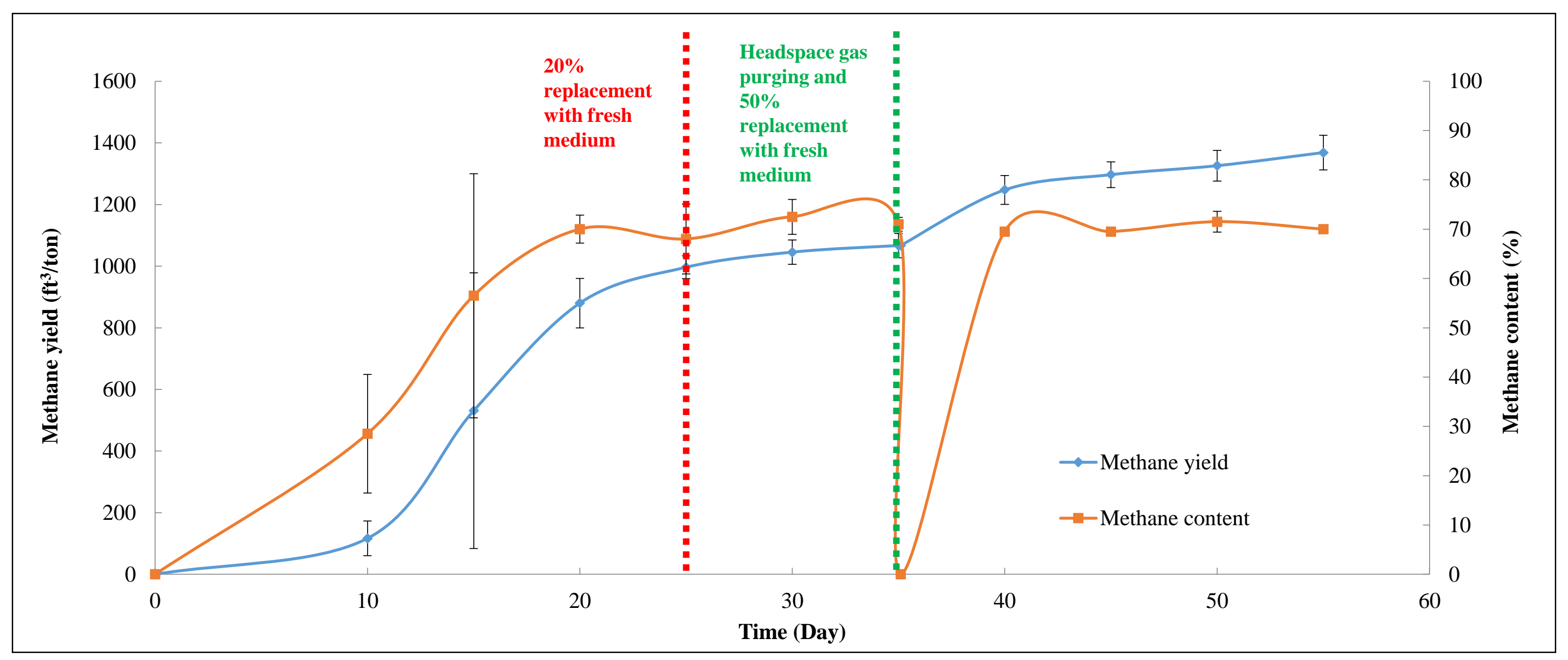


Fig. 6: Methane yield and content responding to headspace purge and replacement of $50 \%$ of the aqueous phase in each reactor.

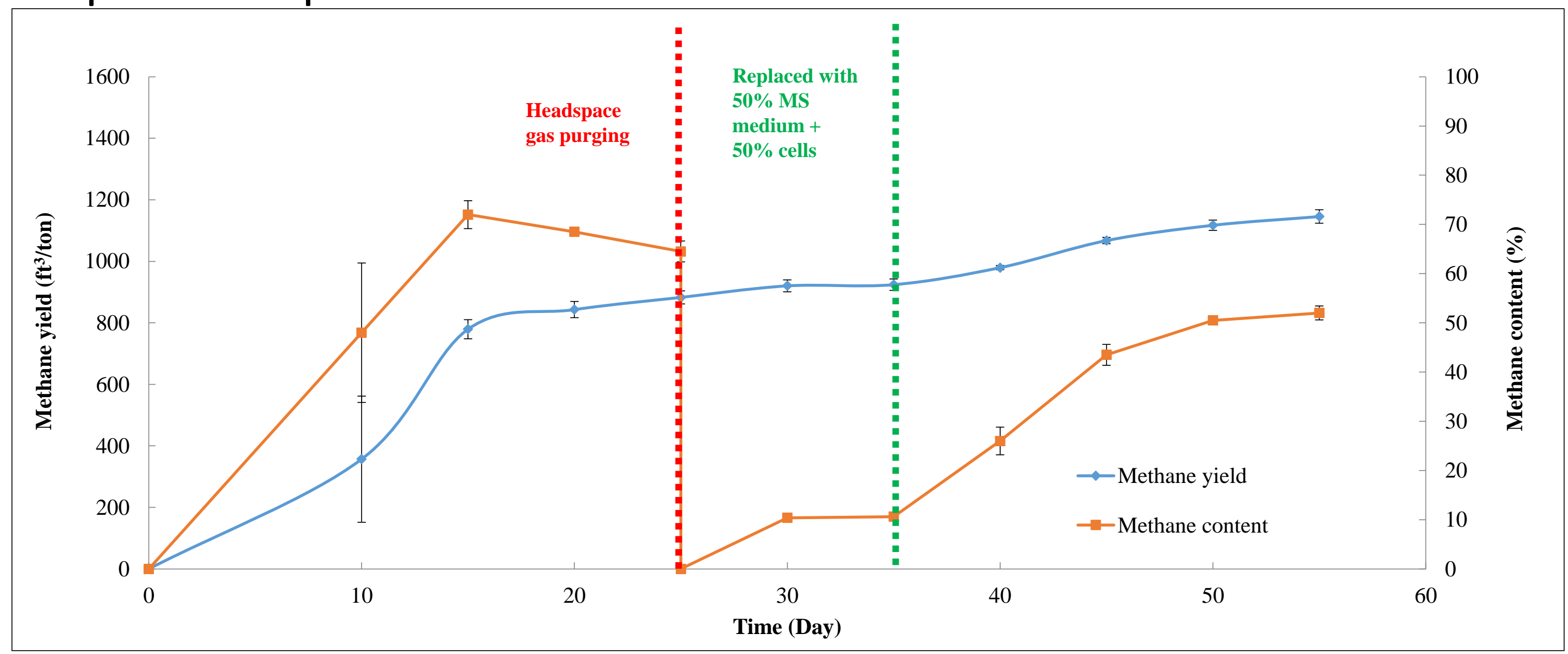

